\title{
Assessing the Effects of Service Quality, Experience Value, Relationship Quality on Behavioral Intentions
}

\author{
Van Dat TRAN* \\ Received: January 01, 2020 Revised: January 29, 2020 Accepted: February 06, 2020.
}

\begin{abstract}
The study aims to examine the relationships between service quality, experience value, relationship quality and behavior intentions. Validated measurements were identified from a literature review. The total of 309 valid respondents were used in this research. The measurement model and the conceptual model depicting hypothesized relationships were evaluated based on the 309 responses using confirmatory factor analysis and a structural equation modeling, accordingly. In addition, this study systematized the concepts, defined and tested the component scales of the relationship model between service quality, experience value, relationship quality and behavior intentions from the collected data, which helps to adequately identify the relationship between the factors in the model as well as the impact. The findings confirm that service quality influences experience values, relationship quality and purchase intention. Service quality, experience value, relationship quality and behavior intentions altogether are not well understood in current literature despite the important implication for managers, academicians and consumers alike. Contributes to a better fit between relationship marketing models and managerial practice in business markets. This study provides managerial implications regarding service quality and experience value so that firms and marketers can consult and apply. Managers should not only focus on the improvement of service quality but overall strategic planning.
\end{abstract}

Key word: Service Quality, Experience Value, Relationship Quality, Behavior Intentions.

JEL Classification Code: M30, M31, M37.

\section{Introduction}

Studies about how service quality affects the success of businesses are undeniable. However, the real value of service quality is based on its decision-making implications. Date back in the late 80 s and early 90 s of the twentieth century, during the emergence of the service industry and findings related to service quality, researchers began to examine marketing strategies and distinguish them as defensive and offensive tactics (Fornell \& Wernerfelt, 1987; Rust \& Zahorik, 1993). Olorunniwo, Hsu, and Udu (2006) tested an integrative model of service quality, customer

*First Author and Corresponding Author. Lecturer, Faculty of Business Administration, Banking University, Ho Chi Minh City, Vietnam [Postal Address: No. 36, Ton That Dam St, Nguyen Thai Binh Ward, District 1, Ho Chi Minh City, 700000, Vietnam] Email: dattv@buh.edu.vn

(c) Copyright: The Author(s)

This is an Open Access article distributed under the terms of the Creative Commons Attribution NonCommercial License (https://creativecommons.org/licenses/by-nc/4.0/) which permits unrestricted no commercial use, distribution, and reproduction in any medium, provided the original work is properly cited. value, relationship quality and behavioral intentions in different service environments. The intended behavior is closely related to actual behavior and has diagnostic value. Thus, behavioral intentions are important indicators for management to understand whether customers would remain with or defect from the company.

We chose to study this topic for two reasons. The first is the gap in the research described in the literature on customer value. For example, Keng, Huang, and Zheng(2007) examined the relationships among service encounters, customer experiential value, and behavioral intention. Mathwick, Malhotra, and Rigdon (2001) investigated the effect of environmental design on experiential value (including consumer return on investment, service excellence, playfulness, and aesthetics). However, previous literature explore the relationship between service quality and relationship quality or between service quality and customer value (Parasuraman, Zeithaml, \& Berry, 1988; Oliver, 1999).

However, none of the existing research has evaluated the relationship among service quality, experience value, 
relationship quality and behavior intention. Thus, suppliers need to make a long-term relationship with customers and increasing customers' satisfaction. Based on the research background and motive, the purposes of this study is to test the relationship among service quality, relationship quality, experience value and behavioral intentions The remainder of the paper is organized as follows: first, Ireview the literature on the conceptualization and measurement of service quality dimensions in conventional and technologyenabled services. Next, the article discusses the research methodology used in the paper as well as the survey instrument used in data collection. Finally, I present the results of our analysis followed by a discussion of the findings.

\section{Literature Review}

\subsection{Service Quality}

Marketing research developed the construct service quality SERVQUAL to measure a consumer's perception of service quality (Parasuraman, Zeithaml, \& Berry, 1988). However, only a limited number of studies have recently included it to measure the successful adoption of technology. Lewis and Boom (1983) defined service quality as a measure of how well the service level delivered matches customer expectations. Lee, Lee, and Kang (2012) indicated that hospitals can improve customer satisfaction and loyalty through efficient operations, employee engagement, and service quality. Feigenbaum (1991) indicated that service quality is customers decision based on their realistic experience with the product/service, measured by customer requests.

Olorunniwo, Hsu, and Udu (2006) indicated that "Responsiveness,"“Tangibility," "Reliability," "Knowledge," and "Accessibility" dimensions contribute significantly to service quality These requests, given or not, were aware of or simply perceived, totally subjective or professional, always represent changing targets in a competitive market. Beside, Wu, Tao, and Yang (2012) showed that an empirical study was conducted to derive the first robust and comprehensive measure of e-banking service quality in Taiwanese. Tabash, Albugami, Salim, and Akhtar (2019) showed that there is a positive impact of good E-service on customers' satisfaction, but it does not override unsatisfactory performance in other areas.

Yang, Cai, Zhou, and Zhou (2005) developed and validated an instrument that measured a user's perceived service quality of information presented on web portals. According to Edvardsson, Thomasson, and Ovretveit (1994), service quality can be defined as the relationship between the customer's expectations of a service and the perception of the service after it was received. Additionally, Wang, Tsai, Chen, and Chang (2012) investigates the effect of emotions displayed and personal selling on customer purchase amount and re-patronage intention in convenience-goods retail service settings. Parasuraman, Zeithaml, and Berry, (1985) developed the SERVQUAL scale. Service quality is still the main method of research and application, using more to modify the dimensions and items from SERVQUAL scale.

This study will use the SERVQUAL scale, a total of five dimensions, asked 22 questions to measure items, moderately modified based on the questionnaire design.

\subsection{Experience Value}

To understand the categories or dimensions on which such assessments are based and to create a customer value framework that captures the domain of the construct in a high-ranking paper on customer value Holbrook (1994) asserted "Value is an interactive relativistic preference experience". Holbrook proposed a typology of consumer value with three dimensions: Extrinsic/ intrinsic; Selforiented/ Other-oriented; Active / reactive. Current marketing literature highlights the importance of the service experience, Mathwick, Malhotra, and Rigdon (2001) suggested that service providers must not only create theatrical environment but also must encourage customers to participate in the service experience. In addition, Zeithaml (1988) investigated whether customers thought of value in four ways: value is low price, value is whatever I want in a product, value is the quality I get for the price I pay, and value is what I get for what I give. Moreover, Mathwick, Malhotra, and Rigdon (2001), consumers today are looking for value, choice, and a great customer experience. Market trends also show that the role of customer experiential value has attracted growing attention among practitioners. The four dimensions of experiential value are as follows: consumer return on investment, service excellence, playfulness, and aesthetic appeal.

\subsection{Relationship Quality}

Crosby, Evans, and Cowles (1990) viewed relationship quality as a high-order construct and should contain at least two dimensions: trust and satisfaction. Oliver $(1997,1999)$ defined satisfaction as pleasurable fulfillment which is sensed by customers in the consumption. Morgan and Hunt (1994) drew the commitment-trust theory by proposing that trust and commitment are two basic constructs for measuring relationship quality. Huntley (2006) views relationship quality as the degree to which buyers are satisfied overtime with the overall partnership as manifested in product quality, service quality, and value for 
money.

Vesel and Zabkar (2010) found that in the retail environment, relationship quality as a second-order factor influences emotional commitment, calculative commitment, and a combined construct of trust and satisfaction. Studies in the first group conceptualize relationship quality mainly through basic dimensions such as satisfaction, trust, or commitment (Crosby, Evans, \& Cowles, 1990). This study applied the relationship quality dimension of Crosby, Evans, and Cowles, (1990); Morgan and Hunt, (1994) developing questionnaire. According Zeihaml (1988), relationship quality from the customer's perspective achieved through the salesperson's ability to reduce perceived uncertainty. Morgan and Hunt's (1994) "The Commitment Trust Theory of Relationship Marketing" researchers started to add commitment as a relationship quality dimension, alongside trust and satisfaction.

\subsection{Behavioral Intensions}

Behavioral intentions in the traditional settings and virtual settings are quite similar (Janda, Trocchia, \& Gwinner, 2002), which normally include repurchase intentions, positive word-of-mouth (Boulding, Kalra, Staelin, \& Zeithaml, 1993; Parasuraman, Zeithaml, \& Malhotra, 2005). In this study, loyalty dimensions represent the results of customer behavior intention so that service providers and customers have strength of relationship. Kim and Yang (2019) showed that overall, external and internal selection factors had a positive influence on repurchase intentions, and in particular, appealing to internal and external selection factors in order to promote repurchase intention. Zeithaml, Berry, and Parasuraman (1996) suggest that favorable behavioral intentions are associated with a service provider's ability to get it. The author used three items to measure this construct that is similar to the domains assessed in the first four of these five outcomes.

\subsection{Hypothesis}

Li, Huang, and Yang (2011) showed that the forms of moderators played by satisfaction are not always the same under different dimensions of service quality (i.e. reliability, responsiveness, assurance, and empathy). Moreover, Venetis (2002) investigated the role of service quality and customer bonding as antecedents of trust, providing further evidence of a positive relationship between service quality and trust between sellers and buyers. Ryu and Han (2010) examined the relationships among three determinants of quality (food, service, and physical environment), satisfaction, and behavioral intentions and found similar results. Cronin, Brady, and Hult (2000) service quality, service value, and satisfaction may all be directly related to behavioral intentions when all of these variables are considered collectively investigates six service industries. From the discussion above the following hypotheses are posited:

H1: Service quality positive effects to experience value.

Mathwick, Malhotra, and Rigdon (2001) showed that experiential value perceptions are strongly tied to interactions between direct usage and distant evaluations of goods and services, and these interactions provide the foundation for experiential value perception According to Wilson (1995) various aspects of experiential value affect consumer behavior. Ha (2018) showed that the satisfaction of customers using ATM cards of Vietcombank Vinh Long is influenced by 4 factors with the order of importance as follows: price, network, reliability, and empathy. Satisfaction, for example, depends on the evaluation of both tangible and intangible attributes, such as food quality, service quality, and atmospherics.

H2: Experience value is positive effects to behavioral intentions.

Chen, Lee, Chen, and Huang (2012) consistently found that service quality had positive significant relationship with tourist satisfaction. Morover, Roberts, Varki, and Brodie (2003) revealed that service quality was positively related to relationship quality and behavioral intention. The relationship quality was also positively related to behavioral intention. Accordingly, we hypothesize that service quality positive effects on relationship quality in different service environment.

H3: Service quality positive effects to relationship qual ity.

Hyun (2010) found that relationship quality was an important predictor of customer loyalty in casual dining restaurants. Similarly, Wetzels, Ruyter, and Birgelen (1998) investigated that the mediating role of relationship quality on the connection between relationship management activities and relationship outcomes in luxury restaurants and found that the effective use of relationship management increased customers' emotional attachment to the restaurant, thereby increasing repurchase intentions (Kim, Lee, \& Yoo, 2006). Omotayo (2011) showed a strong positive relationship between service quality and satisfaction; service quality and loyalty and value offer and satisfaction. Service quality was found to impact positively on satisfaction and loyalty. The result indicated that satisfactory, trust and commitment have positively effect to customer behavioral intentions. Ha and Jang (2009) found 
that relationship quality moderates the relationship between customers' perceived justice during dining experiences and their post-purchase behaviors.

H4: Relationship quality positive effects to behavior int entions.

In many studies, satisfaction has been proven to have correlation with service quality and behavioral intentions, both direct and indirect. Cronin, Brady, and Hult (2000) suggested that the indirect effects of the service quality and value constructs enhanced their impact on behavioral intentions, specifically between service quality, customer satisfaction and behavioral intentions, in which customer satisfaction is an important mediator. According to $\mathrm{Hu}$, Kandampully, and Juwaheer (2009) found that that delivering high quality service and creating superior customer value can result in achieve high customer satisfaction, thus effecting the firm's corporate image, and ultimately leading to consumer retention. Roberts, Varki, and Brodie (2003) found that the relationship quality is not only has a significant difference with the service quality, but also has a better predictability for behavioral intentions than the service quality. Yu, Chang, and Huang (2006) also pointed out that service quality affects behavioral intentions through customer satisfaction in his study in Taiwanese leisure industry. Based on the literatures above I hypothesized that service quality will have a positive effect to behavioral intentions.

H5: Service quality positive effects to behavioral intensions

Kim, Lee, and Yoo (2006) examined tangible and intangible predictors of relationship quality and found that the perception of price fairness significantly impacts trust and satisfaction. Thus, the perception that price is not reasonable (compared to the service received) negatively affects the dining experience leading to a lack of trust in the service provider. Wakefield and Blodgett (1994) found that the effective layout in service facilities generates a positive evaluation in a customer's consumption experience. From the preceding integration of the extant literature on experiential value in consumer behavior, the following hypotheses are proposed concerning the impact of experiential value on relationship quality:

H6: Experience value positive effects to relationship quality.

\section{Research Methodology}

\subsection{The Research Framework}

Figure 1 showed the research framework of this research. The purpose of this study is investigating the relationship among service quality, satisfaction, experience value and behavioral intentions in restaurants service environments through literature review and related study. According to Cronin, Brady, and Hult (2000), service quality positively related to behavioral intentions through experience value and relationship quality, conceptual framework was proposed in this study (see Figure 1)

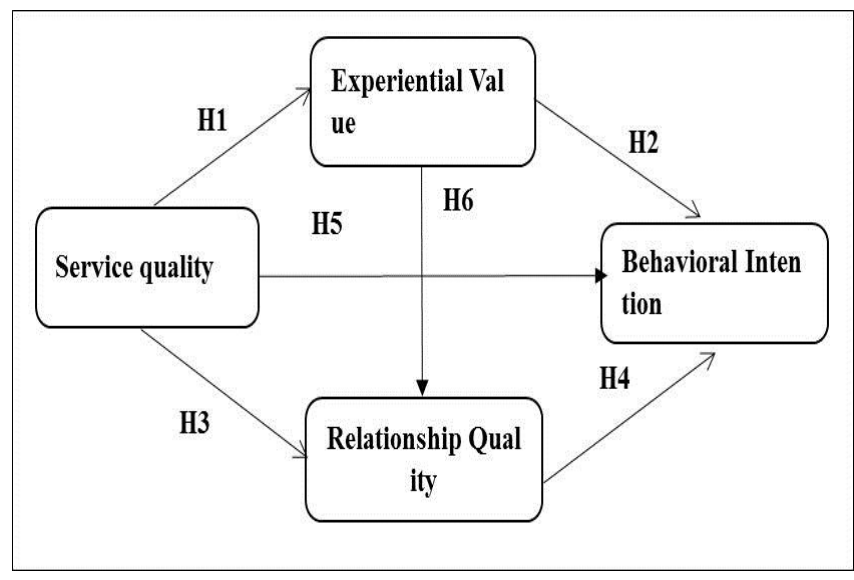

Figure 1: Research Framework

\subsection{Questionnaire Design}

Questionnaires were used in the present study. The survey for the service quality of sports centers represented the first 22 items of the survey based on the SERVQUAL framework of Parasuraman, Zeithaml, and Berry (1988). To measure relationship quality, we included a version of scale that consisted of the 18 relationship quality items from Crosby, Evans, and Cowles (1990); Morgan and Hunt (1994). In order to measure experiential value, modified 15 items of scale developed by (Mathwick, Malhotra, \& Rigdon, 2001)) was used. Finally, to measure behavioral intention, we adopt 3 items from Cronin, Brady, and Hult (2000).

\subsection{Sampling and Data Collection}

The respondents represent in service environments were requested to respond to each survey item in regard to customer relationship in which they were received the service. Because some customers did not complete their questionnaires and had consistent answers for all questions, 19 questionnaires were deleted from the analysis process. After the process of screening and editing, the total of 309 valid questionnaires were used to analyze in this research (see Table 1). 
Table 1: Respondent Profile

\begin{tabular}{|c|c|c|}
\hline Category & $\begin{array}{l}\text { Number of } \\
\text { respondents }\end{array}$ & Percentage \\
\hline \multicolumn{3}{|l|}{ Gender } \\
\hline Male & 114 & $37 \%$ \\
\hline Female & 195 & $63 \%$ \\
\hline \multicolumn{3}{|l|}{ Age } \\
\hline Less than 20 years old & 18 & $6 \%$ \\
\hline 20-30 years old & 140 & $45 \%$ \\
\hline $30-40$ years old & 76 & $24 \%$ \\
\hline $40-50$ years old & 40 & $13 \%$ \\
\hline $50-60$ years old & 27 & $9 \%$ \\
\hline Above 60 years old & 8 & $3 \%$ \\
\hline \multicolumn{3}{|l|}{ Occupation } \\
\hline Student & 130 & $42 \%$ \\
\hline $\begin{array}{l}\text { Banking/financial/ } \\
\text { insurance }\end{array}$ & 54 & $17 \%$ \\
\hline Manufacturing & 30 & $10 \%$ \\
\hline Education/ culture & 48 & $15 \%$ \\
\hline Government & 15 & $5 \%$ \\
\hline Media/publishing & 18 & $6 \%$ \\
\hline Others & 14 & $5 \%$ \\
\hline \multicolumn{3}{|l|}{ Education } \\
\hline $\begin{array}{c}\text { Senior High Diploma or } \\
\text { Below }\end{array}$ & 19 & $6 \%$ \\
\hline $\begin{array}{l}\text { Associate Bachelor } \\
\text { Degree }\end{array}$ & 80 & $26 \%$ \\
\hline Bachelor Degree & 160 & $52 \%$ \\
\hline Master Degree & 40 & $13 \%$ \\
\hline PhD Degree & 10 & $3 \%$ \\
\hline
\end{tabular}

\subsection{Confirmatory Factor Analysis - CFA}

Confirmatory Factory Analysis is a better method to assess the validity and reliability of measures (Bagozzi \& Foxall, 1996). CFA is applied with following important indexes: Chi-square, Chi- square/df, Comparative Fit Index (CFI), Tucker \& Lewis Index (TLI), Root Mean Square Error Approximation (RMSEA). The goodness-of-fit for each model was assessed by examining the chi-square statistic, the comparative fit index (CFI), and the rootmean-square error of approximation (RMSEA), NFI, IFI, and CFI are greater than 0.90 (Hair, Black, Babin, Anderson, \& Tatham, 2006). GFI and AGFI index must exceed 0.8. Chi-square/df should be equal or lower than 2 (Chi-square/df $\leq 3$ can be accepted in some cases) and RMSEA ought to be equal or lower than 0.08 (RMSEA $\leq$
0.05 is deemed excellent) (Hair et al., 2006). Those estimates are the precedents for the reliability of all factors for the next analyzing steps in this research.

Table 2: Testing Results of Reliability and Convergent Validity of Various Conceptions

\begin{tabular}{|c|c|c|c|c|}
\hline Contracts & Items & $\begin{array}{c}\text { Factor } \\
\text { loading }\end{array}$ & $\begin{array}{c}\text { Critical } \\
\text { Reliability }\end{array}$ & AVE \\
\hline \multirow{3}{*}{ TAN } & TAN1 & 0.78 & \multirow{3}{*}{.82} & \multirow{3}{*}{.60} \\
\hline & TAN2 & 0.75 & & \\
\hline & TAN3 & 0.80 & & \\
\hline \multirow{3}{*}{ REL } & REL1 & 0.82 & \multirow{3}{*}{.81} & \multirow{3}{*}{.59} \\
\hline & REL2 & 0.77 & & \\
\hline & REL3 & 0.70 & & \\
\hline \multirow{3}{*}{ ASS } & ASS1 & 0.81 & \multirow{3}{*}{.83} & \multirow{3}{*}{.595} \\
\hline & ASS2 & 0.80 & & \\
\hline & ASS3 & 0.70 & & \\
\hline \multirow{3}{*}{ RES } & RES1 & 0.71 & \multirow{3}{*}{.82} & \multirow{3}{*}{.60} \\
\hline & RES2 & 0.82 & & \\
\hline & RES3 & 0.79 & & \\
\hline \multirow{2}{*}{ EMP } & EMP1 & 0.80 & \multirow{2}{*}{.76} & \multirow{2}{*}{.624} \\
\hline & EMP2 & 0.78 & & \\
\hline \multirow{3}{*}{ AES } & AES1 & 0.79 & \multirow{3}{*}{.823} & \multirow{3}{*}{.608} \\
\hline & AES2 & 0.80 & & \\
\hline & AES3 & 0.75 & & \\
\hline \multirow{4}{*}{ PLA } & PLA1 & 0.77 & \multirow{4}{*}{.85} & \multirow{4}{*}{.600} \\
\hline & PLA2 & 0.80 & & \\
\hline & PLA3 & 0.79 & & \\
\hline & PLA4 & 0.75 & & \\
\hline \multirow{2}{*}{ SE } & SE1 & 0.80 & \multirow{2}{*}{.750} & \multirow{2}{*}{.601} \\
\hline & SE2 & 0.75 & & \\
\hline \multirow{4}{*}{ CRI } & CRI1 & 0.87 & \multirow{3}{*}{.86} & \multirow{3}{*}{.669} \\
\hline & CRI2 & 0.76 & & \\
\hline & CRI3 & 0.80 & & \\
\hline & SAT1 & 0.78 & & \\
\hline SAT & SAT2 & 0.76 & .80 & .573 \\
\hline & SAT3 & 0.73 & & \\
\hline & COM1 & 0.68 & & \\
\hline COM & COM2 & 0.75 & .784 & .549 \\
\hline & COM3 & 0.79 & & \\
\hline & LOY1 & 0.71 & & \\
\hline LOY & LOY2 & 0.77 & .787 & .553 \\
\hline & LOY3 & 0.75 & & \\
\hline & BI1 & 0.80 & & \\
\hline BI & BI2 & 0.79 & .823 & .608 \\
\hline & $\mathrm{BI} 3$ & 0.75 & & \\
\hline
\end{tabular}


CFA result indicated that goodness-of-fit stats of the model are: $\mathrm{GFI}=0.91, \quad \mathrm{AGFI}=0.90, \quad \mathrm{RMSEA}=0.054$, $\mathrm{NFI}=0.94$ and $\mathrm{CFI}=0.92$ prove the validity and reliability of measurements (see Table 2).

\subsection{Reliability and Validity}

According to Hair, Black, Babin, and Anderson (2010), Composite Reliability (CR) must be greater than 0.7 , which should be more reliable. Reliability was assessed in terms of composite reliability, which measured the degree to which items are free from random error and therefore yield consistent results. Composite reliabilities in our measurement model ranged from 0.750 to 0.886 . Convergent validity was assessed in terms of factor loadings and average variance extracted. In addition, In order to measure the dimensions of this study, the author conduct to pre-test questionnaires by applying SPSS statistically analysis to calculate the coefficients. Coefficient alpha for measures of service quality $(\alpha=0.85)$, relationship quality $(\alpha=0.82)$, experience value $(\alpha=0.87)$, behavioral intentions $(\alpha=0.81)$. According to the prior study, convergent validity requires a factor loading greater than 0.60 and an average variance extracted no less than 0.50 .

As shown in Table 2, all items had significant factor loadings higher than 0.60 . Average variances extracted ranged from 0.549 to 0.669 , suggesting adequate convergent validity. Thus, all factors in the measurement model had adequate reliability and convergent validity. Fornell and Larcker (1981), discriminant validity was tested by comparing the average variance extracted (AVE) with the square correlation between constructs.

Table 3 shows the AVE were greater than the squared correlation between any pair of constructs, meaning they exhibit discriminant validity, AVE values calculated also higher than the obligatory value of 0.50 , from 0.55 to 0.61 , suggesting adequate convergent validity. To sum up, there are positive and strong relationships between service quality, experience value, relationship quality and behavioral intentions. Moreover, this research model has appropriated reliability, convergent validity, and discriminant validity of the constructs.

Table 3: AVE and Correlations between the Constructs

\begin{tabular}{|c|c|c|c|c|}
\hline \multirow{2}{*}{} & \multicolumn{5}{|c|}{ Correlation $^{2}$} \\
\cline { 2 - 5 } & SQ & EV & RQ & BI \\
\hline SQ & & & & \\
\hline EV & 0.527 & & & \\
\hline RQ & 0.508 & 0.467 & & \\
\hline BI & 0.425 & 0.540 & 0.432 & \\
\hline
\end{tabular}

\section{Empirical Analysis}

\subsection{Model Tests}

Figure 2 shows the results of the structural model test provided an adequate fit to the data (RMSEA $=.057, \mathrm{CFI}$ $=.940, \mathrm{GFI}=0.91 \mathrm{IFI}=.925, \mathrm{TLI}=.948)$, except the chisquare statistic $\left(\chi^{2}=3448.89, \mathrm{df}=2091, \mathrm{p}<.001\right)$. The result shows the standardized path coefficients and t-values for the hypothesized relationships. All hypotheses were supported:

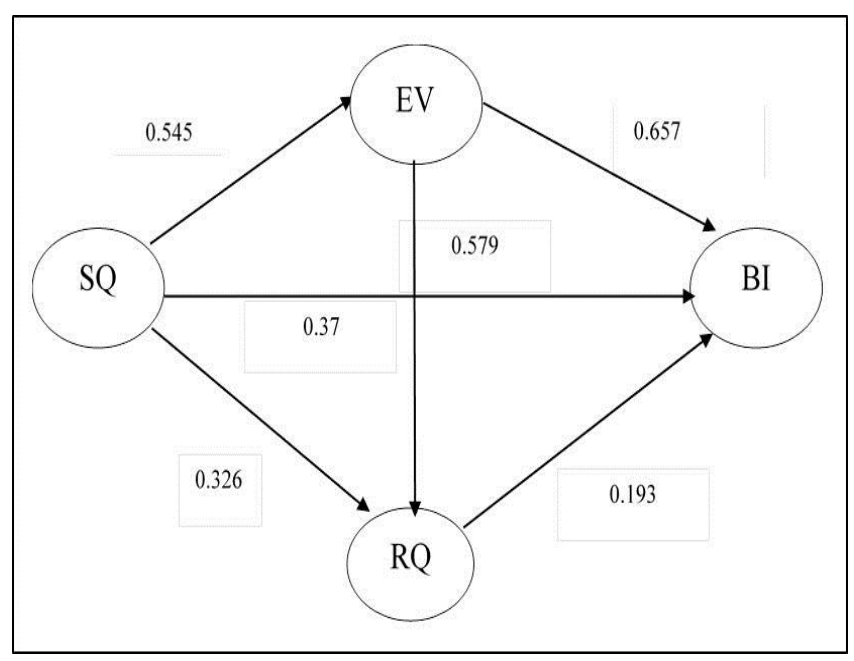

Figure 2: Model Test

The results formulated an SEM using AMOS to analyze our model. Table 4 showed the estimated structural equation model. The estimated model fits the data reasonably well: $(\chi 2 / \mathrm{DF}=1.747$ degrees of freedom, $\mathrm{AGFI}=$ $0.91, \mathrm{CFI}=0.93$, GFI $=0.92, \mathrm{NFI}=0.930$ and RMSEA $=$ 0.051), all accepted. The model's fit as indicated by these indexes was deemed satisfactory. Thus, we could proceed to examine the path coefficients of the structural model. First, the effect of service quality on experience value was significant $\left(\mathrm{H} 1, \beta=0.545^{* * *}, \mathrm{p}<0.001\right)$. Thus, $\mathrm{H} 1$ was supported. Second, the effect of experience value on behavioral intention was significant $\left(\mathrm{H} 2, \beta=0.657^{* * *}\right.$, $\mathrm{p}<0.001$ ), supporting $\mathrm{H} 2$. Beside, the effect of service quality on relationship quality was significant $(\mathrm{H} 3, \beta=$ $\left.0.657^{* * *}, \mathrm{p}<0.001\right)$. Besides, The effect of relationship quality on behavioral intention was significant $(\mathrm{H} 4, \beta=$ $\left.0.193^{* * *}, \mathrm{p}<0.001\right)$ and $\mathrm{H} 5$ was supported $\mathrm{H} 5, \beta=$ $0.579^{* * *}, \mathrm{p}<0.001$ ) (Finally, the effect of experience value on relationship quality was significant $(\mathrm{H} 6, \beta=0.579 * * *$, $\mathrm{p}<0.001)$. H6 was also supported. 
Table 4: The Result of Hypothesis Tests

\begin{tabular}{|c|c|}
\hline Hypotheses Tests & Hypotheses \\
\hline H1: Service quality positively effects to experience value. & Supported \\
\hline $\begin{array}{c}\text { H2: Experience value positively effects to behavioral } \\
\text { intentions }\end{array}$ & Supported \\
\hline $\begin{array}{c}\text { H3: Service quality positively effects to relationship } \\
\text { quality. }\end{array}$ & Supported \\
\hline $\begin{array}{c}\text { H4: Relationship quality positively effects to behavioral } \\
\text { intentions. }\end{array}$ & Supported \\
\hline $\begin{array}{c}\text { H5: Service quality positive relates to behavioral } \\
\text { intentions. }\end{array}$ & Supported \\
\hline $\begin{array}{c}\text { H6: Experience value positive effects to relationship } \\
\text { quality. }\end{array}$ & Supported \\
\hline
\end{tabular}

\section{Conclusion}

From the result of this study, it can be determined that the objectives are achieved. There are positive and significant relationship between service quality, experience value, relationship quality and behavior intentions. In particular, service quality has positive direct impact with experience value, relationship quality. The scale constructing this model has appropriate reliability since all construct measures are kept and the result is statistically significant, proposing valuable findings that contribute greatly in the field of marketing and human behavior. The findings indicated that both service quality and relationship quality lead to experience value. Thus, these findings add weight to Bagozzi's (1992) suggestion that cognitive evaluations precede emotional responses. Cronin, Brady, and Hult (2000) service quality, service value, and satisfaction may all be directly related to behavioral intentions when all of these variables are considered collectively investigates six service industries.

This study systematized the concepts, defined and tested the component scales of the relationship model between service quality, experience value, relationship quality and behavior intentions from the collected data, which helps to adequately identify the relationship between the factors in the model as well as the impact. This makes an important contribution to the marketing research of enterprises in service industries, especially retail businesses. In addition, both of the service quality and consumer behavior is complex processes. This enhance of position set forth above that consumers' decision-making relative to their purchases of service products is a complex and comprehensive process. That is, the significant direct paths indicate that models of consumers' evaluations of services that consider only individual variables or direct effects are likely to result in incomplete assessments of the basis of these decisions.

\subsection{Managerial Implication}

This study offers insight regarding that service quality and experience value are important precedents to other services aspects. As seen from the final research model, service quality has the largest impact to all three other factors: experience value, relationship quality and behavior intentions in a descending order, which means that the better the service quality, the better the outcomes. Relationship quality also affects experience and behavior intentions significantly. In this section, author will provide managerial implications regarding service quality and experience value so that firms and marketers can consult and apply. If managers want to improve the consideration on behavioral intentions, they are not only focus on the improvement of service quality but manager from both of relationship quality and experience value should conduct also overall strategic planning. From a managerial standpoint, this stresses the importance of experience value and behavior intention as a strategic objective and underscores the recent wave of research investigating the construct. For theory, these results add further evidence that service quality is an important decision-making criterion for service consumers. Finally, responsiveness is also a key determinant. Managers should operate an effective customer service team, with inquiries answered immediately and carefully joyful, warm-voiced, friendly people should be used in contact center to take care of customers. This will elevate both service quality and customer satisfaction. In addition, customers' interest must be taken seriously, because when they place their experience value in the firm and spend money on it, they would expect it to be fair. This can be implemented by solving issues and inquiries rapidly is a way to improve service quality.

\subsection{Limitations and Recommendation for Future Studies}

The next limitation is that respondents for this research is almost students and officers who are in middle-level income group. The author could not interact with ones in high-income class. They can have other opinions about experiencing difference service environment and concerning products/services. Those opinions can make a contribution to the more objective observations of customer behaviors about service quality and behavior intention. In addition, the topic is only stop at testing the relationship between research concepts but not to analyze the behavior of different target groups in these relationships. Finally, the author did not investigate the direct relationship between service quality and behavioral intentions, as the main point of the study is to examine whether there is a relationship 
between them through mediators experience value and relationship quality. Future research should examine both direct and indirect as well.

\section{References}

Bagozzi, R., \& Foxall, G. (1996). Construct validation of a measure of adaptive-innovative cognitive styles in consumption. International Journal of Research in Marketing, 13, 201-213.

Boulding, W., Kalra, A., Staelin, R., \& Zeithaml, V. A. (1993). A dynamic process model of service quality: From Expectations to Behavioral Intentions. Journal of Marketing Research, 30(1), 7-27.

Chen, C. M., Lee, H. T., Chen, S. H., \& Huang, T. H. (2012). Tourist behavioural intentions in relation to service quality and customer satisfaction in Kinmen National Park, Taiwan. International Journal of Tourism Research, 13(5), 416-435.

Cronin, J. J., Brady, M. K., \& Hult, G. T. (2000). Assessing the effects of quality, value, and customer satisfaction on consumer behavioural intentions in service environments. Journal of Retailing, 76(2), 193-218.

Crosby, L. A., Evans, K. R., \& Cowles, D. (1990). Relationship quality in services selling: An interpersonal influence perspective. Journal of Marketing, 54(7), 68-81.

Edvardsson, B., Thomasson, B. \& Ovretveit, J. (1994). Quality of service: Making it really work. London, UK: McGraw-Hill.

Feigenbaum, A. V. (1991). Total quality contro (3rd ed.). New York, NY: McGrawHill, Inc.

Fornell, C., \& Wernerfelt, B. (1987). Defensive marketing strategy by customer complaint management: A theoretical analysis. Journal of Marketing Science, 7(3), 287-298.

Fornell, C., \& Larcker, D. F. (1981). Evaluating structural equation models with unobservable variables and measurement error. Journal of Marketing Research, 18(1), 3950.

Ha, J., \& Jang, S. (2009). Perceived justice in service recovery and behavioral intentions: The role of relationship quality. International Journal of Hospitality Management, 28(3), 319327.

Ha, N. K. G (2019). Customer satisfaction towards ATM services: a case of Vietcombank Vinh Long, Vietnam. Journal of Asian Finance, Economics and Business, 6(1), 141-148. http://doi.org/10.13106/jafeb.2019.vol6.no1.141

Hair, J., Black, B., Babin, B., Anderson, R., \& Tatham, R. (2006). Multivariate Data Analysis (6th edition). Upper Saddle River, NJ: Prentice-Hall.

Holbrook, M. B. (1994). Nature of consumer value: An axiology of services in the consumption experience. In R. T. Rust \& O. R. Oliver (Eds.), Service quality: New directions in theory and practice (pp. 21-71). Newbury Park, CA: Sage

Hyun, S. S. (2010). Predictors of relationship quality and loyalty in the chain restaurant industry. Cornell Hospitality Quarterly, 51(2), 251-267.

Hu, H. H., Kandampully, J., \& Juwaheer, T. D. (2009). Relationships and impacts of service quality, perceived value, satisfaction, and image: An empirical study. The Service
Industries Journal, 29(2), 111-125.

Huntley, J. K. (2006). Conceptualization and measurement of relationship quality: linking relationship quality to actual sales and recommendation intention. Industrial Marketing Management, 35, 703-714.

Janda, S., Trocchia, P. J., \& Gwinner, K. P. (2002). Consumer perceptions of Internet retail service quality. International Journal of Service Industry Management, 13(5), 412-431.

Keng, J. C., Huang, T. L., \& Zheng, L. J. (2007). Modeling service encounters and customer experiential value in retailing. International Journal of Service Industry Management, 18(4), 349367.

Kim, W. G., Lee, Y., \& Yoo, Y. (2006). Predictors of relationship quality and relationship outcomes in luxury restaurants. Journal of Hospitality and Tourism Research, 30(2), 143-169.

Kim, Y. E., \& Yang, H. C. (2020). The effects of perceived satisfaction level of high-involvement product choice attribute of Millennial generation on repurchase intention: Moderating effect of gender difference. Journal of Asian Finance, Economics and Business, 7(1), 131-140. https://doi.org/10.13106/jafeb.2020.vol7.no1.131

Lee, S. M., Lee, D. H., \& Kang, C. Y. (2012). The impact of highperformance work systems in the health-care industry: employee reactions, service quality, customer satisfaction, and customer loyalty. Service Industries Journal, 32(1), 17-36.

Lewis, R. C., \& Booms, B. H. (1983). The marketing aspects of service quality. In L. Berry, G. Shostack, \& G. Upah (eds.), Emerging perspectives on services marketing (pp. 99-104). Chicago, IL: American Marketing Association.

Li, S., Huang, Y., \& Yang, M. M. (2011). How satisfaction modifies the strength of the influence of perceived service quality on behavioral intentions. Leadership in Health Services, 24(2), 91-105.

Mathwick, C., Malhotra, N., \& Rigdon, E. (2001). Experiential value: conceptualization, measurement and application in the catalog and Internet shopping environment. Journal of Retailing, 77, 39-56.

Morgan, R. M., \& Hunt, S. D. (1994). The commitment-trust theory of relationship marketing. Journal of Marketing, 58(7), 20-38.

Oliver, L. R. (1997). Satisfaction: A behavioral perspective on the customer. New York, NY: McGraw-Hill.

Oliver, R. L. (1999). Whence consumer loyalty? Journal of Marketing, 63, 33-44.

Olorunniwo, F., Hsu, M. K., \& Udo, G. J. (2006). Service quality, customer satisfaction, and behavioural intentions in the service factory. Journal of Services Marketing, 20(1), 59-72.

Omotayo, O. (2011). Sales promotion and consumer loyalty: A study of Nigerian Telecommunication Industry. Journal of Competitiveness, 4, 66-77.

Parasuraman, A., Zeithaml, V. A., \& Berry, L. L. (1985). A conceptual model of service quality and its implications for future research. Journal of Marketing, 49(3), 41-50.

Parasuraman, A., Zeithaml, V. A., \& Berry, L. L. (1988). Servqual: A multiple-item scale for measuring consumer perceptions of service quality. Journal of Retailing, 64(1), 12-40.

Parasuraman, A., Zeithaml, V. A., \& Malhotra, A. (2005). E-SQUAL: A multiple-item scale for assessing electronic service 
quality. Journal of Service Research, 7(3), 213-234.

Rust, R. T., \& Zahorik, A. J. (1993). Customer satisfaction, customer retention, and market share. Journal of Retailing, 69, 193-215.

Ryu, K., \& Han, H. (2011). New or Repeat Customers: How Does Physical Environment Influence Their Restaurant Experience? International Journal of Hospitality Management, 30(3), 599-611.

Roberts, K., Varki, S., \& Brodie, R. (2003). Measuring the quality of relationships in consumer services: an empirical study. European Journal of Marketing, 37, 169-96.

Tabash, M. I., Albugami, M. A., Salim, M., \& Akhtar, A. (2019). Service quality dimensions of e-retailing of Islamic banks and its impact on customer satisfaction: An empirical investigation of Kingdom of Saudi Arabia. Journal of Asian Finance, Economics and Business, 6(3), 225-234. https://doi.org/10.13106/jafeb.2019.vol6.no3.225

Vesel, P., \& Zabkar, V. (2010). Comprehension of relationship quality in the retail environment. Managing Service Quality 20(3), 213-235.

Venetis, K. A., \& Ghauri, P. N. (2002). The importance of service quality on customer retention: an empirical study of business service relationships. Proceedings of the Marketing in a Global Economy Conference, Buenos Aires, June 28, 215-224

Wang, E. S., Tsai, B. K., Chen, T. L., \& Chang, S. C. (2012). The influence of emotions displayed and personal selling on customer behaviour intention. Service Industries Journal, 32(3), 353-366.

Wakefield, K. L., \& Blodgett, J. G. (1994). The importance of servicescapes in leisure service setting. Journal of Services Marketing, 8(3), 66-76.

Wetzels, W., Ruyter, W. D., \& Birgelen, M. V. (1998). Marketing service relationships: the role of commitment. Journal of Business \& Industrial Marketing, 13(4/5), 406-423.

Wilson, D. T. (1995). An integrated model of buyer-seller relationships. Journal of the Academy of Marketing Science, 23(4), 335-345.

Wu, Y. L., Tao, Y. H., \& Yang, P. C. (2012). Learning from the past and present: measuring Internet banking service quality. Service Industries Journal, 32(3), 477-497.

Yang, Z., Cai, S., Zhou, Z., \& Zhou, N. (2005). Development and validation of an instrument to measure user perceived quality of information presenting Web portals. Information \& Management, 42(4), 575-589.

Yu, C. H., Chang, H. C., \& Huang, G. L. (2006) A Study of service quality, customer satisfaction and loyalty in Taiwanese leisure industry. The Journal of American Academy of Business, 9(1), 126-132.

Zeithaml, V. A. (1988). Consumer perceptions of price, quality, and value: a means-end model and synthesis of evidence. Journal of Marketing, 52(3), 2-22.

Zeithaml, V. A., Berry, L. L., \& Parasuraman, A. (1996). The behavioral consequences of service quality. Journal of Marketing, 60(2), 31-46.

Wilson, D. T. (1995). An integrated model of buyer-seller relationships. Journal of the Academy of Marketing Science, 23(4), 335-345. 